\begin{tabular}{|l|l|l||}
\hline \multicolumn{2}{|c|}{ PublisherInfo } \\
\hline \hline PublisherName & $:$ & BioMed Central \\
\hline \hline PublisherLocation & $:$ & London \\
\hline \hline PublisherImprintName & $:$ & BioMed Central \\
\hline \hline
\end{tabular}

\title{
CD30 involvement in self tolerance of T cells
}

\begin{tabular}{|l|l|l||}
\hline \multicolumn{2}{|c||}{ ArticleInfo } \\
\hline \hline ArticleID & $:$ & 240 \\
\hline \hline ArticleDOI & $:$ & $10.1186 /$ ar-1999-66731 \\
\hline \hline ArticleCitationID & $:$ & 66731 \\
\hline \hline ArticleSequenceNumber & $:$ & 197 \\
\hline \hline ArticleCategory & $:$ & Paper Report \\
\hline \hline ArticleFirstPage & $:$ & 1 \\
\hline \hline ArticleLastPage & $:$ & 4 \\
\hline \hline & & RegistrationDate : 1999-9-20 \\
\hline ArticleHistory & $:$ & OnlineDate \\
\hline \hline ArticleCopyright & $:$ & Current Science Ltd1999-9-20 \\
\hline \hline ArticleGrants & $:$ & \\
\hline \hline ArticleContext & $:$ & 130753311 \\
\hline \hline
\end{tabular}




\section{Keywords}

CD30, CD8 T cells, diabetes, self tolerance,

\section{Context}

CD30 is a member of the tumour necrosis factor (TNF) receptor superfamily, and is expressed on activated T and B cells. Here, the authors investigate the role of CD30 in self-tolerance of autoreactive $\mathrm{CD}^{+} \mathrm{T}$ cells. An autoimmune diabetes model system was used where ovalbumin (ova)-specific $\mathrm{CD} 8^{+} \mathrm{T}$ cells from the OT-1 transgenic mouse line were adoptively transferred into unirradiated transgenic mice that expressed ova in the pancreatic beta cells and the proximal tubular cells of the kidney (RIP-mOVA mice). In this model, wild type OT-1 CD ${ }^{+} \mathrm{T}$ cells caused diabetes only when transferred in large numbers, with lower doses being effectively tolerised. Such tolerance is believed to be due to autoantigen from pancreatic cells moving to draining lymph nodes, where it causes activation and subsequent deletion of autoreactive T cells - termed cross-tolerance. This mechanism is dependent on Fas (CD95). The role of CD30 in the maintenance of tolerance was investigated by adoptively transferring CD30-deficient (CD30-/-) OT-1 cells into RIP-mOVA mice, and following the fate of these T cells.

To investigate the role of CD30 in self-tolerance of $\mathrm{CD}^{+} \mathrm{T}$ cells, using an autoimmune diabetes model system.

\section{Significant findings}

In contrast to wild-type OT-1 CD8 ${ }^{+}$T cells, CD30-/- OT-1 T cells were highly diabetogenic, with as few as 160 cells causing diabetes in the adoptive transfer model. Disease onset was rapid, occurring as early as four days after transfer. Flow cytometric analysis of spleen and lymph nodes suggested an increase or expansion in the number of CD30-/- T cells, but not of wild-type OT-1 cells, peaking 4?5 days after transfer. These data suggest CD30 signalling may normally limit the proliferation of autoreactive $\mathrm{CD}^{+}$T cells. Immunohistology data suggested that CD30-/- OT-1 cells, but not wild-type OT-1 cells, were actively proliferating in the pancreatic islets. The authors suggest expansion occurred preferentially in the pancreas rather than the lymph nodes. To investigate whether priming in the lymph 
nodes is a prerequisite for antigen recognition in the pancreatic islets, bone marrow chimaeric mice were generated using congenic strains that differed at the MHC class I molecule H-2 K (C57BL6 H-2Kb and bml H-2Kbml). Results show that priming in draining lymph nodes (by bone marrow derived antigenpresenting cells (APC) was necessary to allow expansion of the CD30-/- $\mathrm{CD}^{+}{ }^{+}$cells in the pancreatic islets. In addition, $\mathrm{T}$ cell expansion required secondary recognition of antigen in the parenchymal pancreatic tissue.

\section{Comments}

$\mathrm{CD}^{+} \mathrm{T}$ cells are believed to play an important role in a number of autoimmune diseases. These results suggest there are at least two levels of control of such cells, mediated by Fas or CD30. For selftolerance to occur the CD30 signal would be necessary to limit the expansion of autoreactive T cells. However, in circumstances such as $\mathrm{T}$ cell immunity to tumors, activation and proliferation of $\mathrm{T}$ cells is necessary. The authors speculate that CD30 signalling may be suppressed or decoupled during inflammation or infection, allowing activated $\mathrm{CD}^{+} \mathrm{T}$ cells to undergo amplification in the parenchymal tissue when they encounter tumor or infected cells. Blockade of CD30 signalling for enhancement of $\mathrm{CD}^{+} \mathrm{T}$ cell function may be a useful adjunct during antitumor immunotherapy.

It should be noted that in vitro proliferation to ova-bearing cells was not increased when T cells were deficient in CD30, suggesting that some specific characteristics of the in vivo model were necessary to demonstrate the effect of CD30 deficiency.

\section{Methods}

OT-1 and OT-1 CD30-/- CD ${ }^{+}$T cells were prepared from lymph nodes of transgenic animals. Erythrocytes, B cells and $\mathrm{CD}^{+}{ }^{+} \mathrm{T}$ cells were depleted by treatment with specific antibodies and complement. Purified cells were analysed by flow cytometry prior to intavenous injection into recipient mice.

Bone marrow chimaeric mice were generated using lethally irradiated 7-8 week old mice which were reconstituted with 5,000,000 T-cell-depleted bone marrow cells. These mice were further depleted of T cells by intraperitoneal injection of Thy-1-specific T24 ascites. The number of OT-1 cells in recipient mice was determined using flow cytometry. Pooled lymph node and spleen cells were depleted of erythrocytes and stained for CD8 and OT-1 T cell receptor chains $\mathrm{V}_{\mathrm{a}} 2$ and $\mathrm{V}$ ?5. The number of OT-1 cells was calculated relative to the number of $\mathrm{CD}^{+} \mathrm{V}_{\mathrm{a}} 2^{+} \mathrm{V} ? 5^{+} \mathrm{T}$ cells in a normal mouse.

Frozen sections of pancreatic tissue were stained for BrdU incorporation, to measure T cell proliferation. 


\section{References}

1. Kurts C, Carbone FR, Krummel MF, Koch KM, Miller JF, Heath WR: Signalling through CD30 protects against autoimmune diabetes mediated by CD8 T cells. Nature. 1999, 398: 341-344.

This PDF file was created after publication. 